\title{
Toxicological and Biochemical Investigation of certain Herbicides on Culex pipiens L. (Diptera: Culicidae) Mosquitoes under Laboratory Conditions
}

\author{
${ }^{1}$ Reda M. Saba, ${ }^{2}$ Ibrahim A. Mohamed, ${ }^{2}$ Mohamed A. I. Ahmed \\ 1Plant Protection Department, Faculty of Agriculture, Al-Azhar University, Assiut 71524, Egypt. \\ 2Plant Protection Department, Faculty of Agriculture, Assiut University, Assiut 71526, Egypt.
}

Correspondence Author: Dr. Mohamed Ahmed Ibrahim Ahmed, Assiut University, Plant Protection Department, Faculty of Agriculture, Assiut 71526. Egypt.

E-mail: maiaf2000@gmail.com; Tel.: +201113991177; Fax: +20882080384

Received date: 10 January 2018, Accepted date: 28 February 2018, Online date: 10 March 2018

Copyright: (c) 2018 Reda M. Saba et al. This is an open-access article distributed under the terms of the Creative Commons Attribution License, which permits unrestricted use, distribution, and reproduction in any medium, provided the original author and source are credited.

\begin{abstract}
The knowledge of how herbicides affect mosquito ecology and behavior is confined. This study evaluated the toxicity of six selected herbicides in comparison with one insecticide (thiamethoxam + chlorantraniliprole) on $4^{\text {th }}$ instar larvae of Culex pipiens after 24, 48, and 72-h exposure. Plus, this study investigated the biochemical effects of these pesticides on $4^{\text {th }}$ instar larvae using sodium dodecyl sulphate-total protein (SDS-total protein) technique. As a result, thiamethoxam+ chlorantraniliprole was the most toxic pesticide among all tested pesticides ( $\mathrm{LC}_{50}$ was $0.0083,0.0016$, and $0.0004 \mu \mathrm{g} / \mathrm{ml}$ after 24,48 , and 72-h exposure, respectively) while mesosulfuron-methyl+iodosulfuron-methyl is considered the most potent herbicide among the evaluated herbicides ( $\mathrm{LC}_{50}$ was $0.67,0.45$, and $0.36 \mu \mathrm{g} / \mathrm{ml}$ after 24,48 , and 72 -h exposure, respectively). Clodinafop-propargyl+pinoxaden, diclofop-methyl, bromoxynil octanoate, and fenoxaprop-p-ethyl were demonstrated to be of moderate toxic herbicides on the mosquito larvae. In biochemical studies, new bands of protein were found rather than those in the control. For instance, Three new bands with molecular weight of approximately 41, 22, and $19 \mathrm{kDa}$ were detected in Culex pipiens larvae samples treated in the same of these herbicides with glyphosate isopropylamine, diclofopmethyl, and mesosulfuron-methyl+iodosulfuron-methyl. Future studies should be conducted to investigate the mechanisms of the selected herbicides that induced changes in mosquito to get better comprehension of these functions.
\end{abstract}

Key words: Culex pipiens, herbicides, mosquito control, glyphosate, SDS-total protein technique

\section{INTRODUCTION}

Generally, more than three thousand mosquito's species are well-known in the world [1-4]. Culex pipiens L. is considered one of the most dominant mosquito species not only in Egypt but also in other countries [5-6]. However, Culex pipiens acts as the main vector of various human and animal blood pathogens like Bancroftian filariasis, Rift valley fever virus, Usutu virus, West Nile virus, and avian malaria (Plasmodium spp.) [6, 7-9]. Further, immature stages of mosquitos and other aquatic insects spend their life in aquatic habitats like irrigation canals, lakes, small ponds, drains, puddles, ditches and other water pathways [10-12].

Interestingly, wide different forms of pesticides such as insecticides and herbicides are used as the main tool to control target pests in recent agricultural systems worldwide. In this regard, herbicides ranked as the first one (more than 60\%) of total used pesticides in the global. Glyphosate, and members of acetylCoA carboxylase (ACCase) and acetolactate synthase (ALS)-inhibitors herbicides are the most common and important herbicides used for control broad-spectrum of weeds in crop and non-crop areas [13].

In accordance with widespread, intensive and continuous used of wide forms of pesticides include herbicides that used in control invasive plants and weeds in agricultural and non-agricultural regions, it led to contaminate these breeding sites and exposed the habit organisms to these pesticides and its metabolic via direct application or indirectly by runoff, aerial drift, and overspray [14-15]. Many herbicides such as glyphosate, bromoxinal, atrazine and some ACCase and ALS-inhibitors are persistent as residues in several surface water sources of the aquatic ecosystem and in some cases the herbicide residues were detected in hazardous levels [16-17]. Adversely impacts of some herbicides such as glyphosate, certain ALS- and ACCase-inhibitors have been confirmed on different insects and on some various aquatic animals (i.e., fish, snail, amphibian and arthropods) and these compounds can affect the survival, behavior, physiology, reproductive, fecundity and development of the former organisms [14, 18-20]. Samosoe (1995) [20] found that bromxoynil, haloxyfop, and pyridate exhibited toxicity on Aleochara bilineata and reduced its survival, egg production, and hatching. Disruptive impacts of direct and indirect harmful effects of herbicides such as many ACCase-inhibitors (i.e., sethoxydim, fluazifop, and haloxyfop) have been investigated on a wide spectrum of insects such as Spodoptera littoralis Boisd. and Icaricia icarioides Blackmorei. These herbicides affected on the morphological shape survival, fertility, and development egg [21-24].

Recently, numerous studies were conducted about the dexterous effect of some herbicides on immature and adult stages of different mosquito species in the world. For example, Mohamed et al. (2016) [18] studied the toxicity effects of glyphosate, glufosinate and certain AOPP and CHD herbicides on larvae of Culex pipiens in Egypt. Persistent of glyphosate in aquatic habits can decrease the populations of mosquitoes which feed on some aquatic plant species [25]. The 
sublethal concentrations of glyphosate and atrazine altered the larval development time and sex ratio of emerging adult's Aedes aegypti and Aedes albopictus [26]. Also, glyphosate and imazamox induced potential effect on larvae of Aedes aegypti [12].

Negatively, persistence of some herbicides (e.g., glyphosate) on mosquitoes aquatic breeding sites led to increase the mosquitoes resistance to various types of pesticides and that action have been occurred through inductions of some detoxification enzymes in these pests which involved in the metabolism and degradation of these pesticides [27-28]. In this interim, some genetics methods such as isozyme analysis and sodium dodecyl sulphate-total protein (SDS-total protein) have been utilized as a bio-indicator assay for the changes occurred in the molecular basis in organisms (i.e., insects and snails) exposed to different types of xenobiotic and the environmental stress such as accumulation of pollutants [19, 29].

Herein we investigated biochemical and toxicological efficacy of certain commonly and widely used herbicides in Egypt for instance, mesosulfuron-methyl + iodosulfuron-methyl, clodinafop-propargyl + pinoxaden, diclofop-methyl, bromoxynil octanoate, fenoxaprop-p-ethyl, and glyphosate isopropylamine in comparison with the insecticide (Thiamethoxam + chlorantraniliprole) on $4^{\text {th }}$ instar larvae of Culex pipiens under laboratory conditions. The biochemical effect of these pesticides on $4^{\text {th }}$ instar larvae using sodium dodecyl sulphate-total protein (SDS-total protein) technique was also conducted.

\section{Mosquitoes:}

\section{MATERIALS AND METHODS}

Culex pipiens larvae were collected from Arab El-Madabegh region (Westernmost station of Assiut Governorate, Egypt) then transferred directly to the pesticides toxicology laboratory, Department of Plant Protection, Faculty of Agriculture, Assiut University for preside the experiments

Chemicals:

Six herbicides and thiamethoxam + chlorantraniliprole as an insecticide were tested. The tested herbicides included three ACCase-inhibitors, clodinafoppropargyl+pinoxaden (Traxoase 4.5\% EC, Syngenta Co.), diclofop-methyl (Illoxan 36\% EC, Bayer CropScience Co.), and fenoxaprop-p-ethyl (Puma super 7.5\% EW, Bayer CropScience Co.). An Epsps-inhibitor, glyphosate isopropylamine (Herbazd 48\% EC, Monsanto Co.), an ALS-inhibitor, mesosulfuronmethyl+iodosulfuron-methyl (Atlantis 1.2\% OD, Bayer CropScience Co.), and a photosynthesis-inhibitor, bromoxynil octanoate (Brominal 24\% EC, BSAF Co.),

Toxicological bioassay:

The standard procedures of the pesticides bioassay were conducted according to WHO, 1981 [30] and Mohamed et al., 2016 [18]. However, six concentrations of each tested pesticide were set by using tap water. Four replicates were prepared for each concentration. Further, a set of ten $4^{\text {th }}$ instar larvae of Culex pipiens with uniform size were devolved to different plastic cups which containing $100 \mathrm{ml}$ of appropriate concentrations of each tested pesticide. Controls were only contained tap water. As a source of food, mixture of dry yeast and grinded bread were given. The bioassay was kept under laboratory conditions at $25 \pm 2$ ${ }^{\circ} \mathrm{C}$ and $60 \pm 5 \%$ relative humidity. Mortality was determined after 24,48 , and 72-h of exposure. Larvae were diagnosed as dead if they declined to proceed to move after probing with soft brush in the siphon or cervical area [31].

Biochemical determination of total protein content:

The $\mathrm{LC}_{50}$ values of all tested pesticides from the toxicological bioassay experiments were estimated first then each one was prepared freshly in the laboratory. More than one thousands of $4^{\text {th }}$ instar larvae of Culex pipiens were exposed to the $\mathrm{LC}_{50}$ concentration of each pesticide. After 24-h of the treatment, the survival larvae were assembled and placed in eppendorf plastic tubes and kept after that in ice $\left(-4^{\circ} \mathrm{C}\right)$ till transferred to the fridge to keep it at $-80^{\circ} \mathrm{C}$. SDS-total protein content of Culex pipiens larvae was determined at the Genetic Engineering and Molecular Biology Research Center, Assiut University according to Bradford (1976) [32] with slightly modified.

Data analysis:

$\mathrm{LC}_{50}$ and $\mathrm{LC}_{90}$ values and their corresponding $95 \%$ confidence limits (CLs), and the slopes were estimated using IBM SPSS statistics 23 program (SPSS Inc., Chicago, IL). Figures were created by using GraphPad Prism 6.07 software (San Diego, CA, USA). Toxicity index was calculated as follows:

Toxicity index $=[(\mathrm{LC}$ value of the most toxic tested pesticide $/ \mathrm{LC}$ value of the tested pesticide $) \times 100]$.

\section{RESULTS AND DISCUSSIONS}

Toxicity of selected herbicides in comparison with one insecticide on fourth instar larvae of Culex pipiens after 24, 48, and 72-h was shown in tables 1-3. In spit thiamethoxam+ chlorantraniliprole was the most toxic pesticide among all tested pesticides $\left(\mathrm{LC}_{50}\right.$ was $0.0083,0.0016$, and $0.0004 \mu \mathrm{g} / \mathrm{ml}$ after 24,48 , and $72-\mathrm{h}$ exposure, respectively), mesosulfuron-methyl+iodosulfuron-methyl is considered the most potent herbicide among evaluated herbicides ( $\mathrm{LC}_{50}$ was $0.67,0.45$, and $0.36 \mu \mathrm{g} / \mathrm{ml}$ after 24, 48, and 72-h exposure, respectively). However, clodinafop-propargyl+pinoxaden, diclofop-methyl, bromoxynil octanoate, and fenoxaprop-pethyl were deemed to be of moderate toxic herbicides on fourth instar larvae of Culex pipiens. Further, Glyphosate isopropylamine was counted to be the lowest potent herbicide $\left(\mathrm{LC}_{50}\right.$ was $17484.02,7042.38$, and $5217.25 \mu \mathrm{g} / \mathrm{ml}$ after 24,48 , and 72 -h exposure, respectively). The same trend of toxicity efficacy of selected pesticides was observed after 48 and 72-h exposure.

Based on the slope values of the toxicity selected pesticides, $4^{\text {th }}$ instar larvae of Culex pipiens demonstrated relative high homogeneity response to glyphosate isopropylamine herbicide (slope value was 17.26) especially after 24-h exposure. In contrast, Culex pipiens exhibited heterogeneity response to clodinafoppropargyl+pinoxaden and mesosulfuron-methyl+iodosulfuron-methyl herbicides (slope values were 0.53 and 0.54 , respectively). However, moderate homogeneity was observed in diclofop-methyl, bromoxynil octanoate, thiamethoxam+chlorantraniliprole, and fenoxaprop-p-ethyl (slope values were 1.49, 2.04, 2.81, and 4.23, respectively). Interestingly, comparable trend was displayed after 48 and 72 -h exposure.

The toxicity index of selected pesticides was exhibited in Figure 1. In this interim, for $\mathrm{LC}_{50}$ values after 24-h exposure, the values were 100, 1.24, 0.62, 0.19, $0.09,0.03$ and 0.00006 for thiamethoxam+chlorantraniliprole, mesosulfuron-methyl+iodosulfuron-methyl, clodinafop-propargyl+pinoxaden, diclofop-methyl, bromoxynil octanoate, fenoxaprop-p-ethyl, and glyphosate isopropylamine, respectively, whereas for the $\mathrm{LC}_{90}$ values after 24-h exposure were 100, 1.83, 1.18, $0.20,0.09,0.04$, and 0.0001 . Mesosulfuron-methyl+iodosulfuron-methyl was more toxic than clodinafop-propargyl+pinoxaden diclofop-methyl, bromoxynil octanoate, fenoxaprop-p-ethyl, and glyphosate isopropylamine by 2.00-, 6.63-, 13.51-, 42.85-, and 26095.55-fold, respectively. However, after 72-h exposure, mesosulfuron-methyl+iodosulfuron-methyl was more toxic by 2.92-, 5.72-, 4.58-, 44.58-, and 14492.36-fold, respectively.

The samples of Culex pipiens larvae showed number of protein bands ranging from 7 to 12 bands (Table 4 and figure 2). Clodinafop-propargyl+pinoxaden, fenoxaprop-p-ethyl, diclofop-methyl, bromoxynil octanoate, glyphosate isopropylamine, mesosulfuron-methyl+iodosulfuron-methyl and thiamethoxam+chlorantraniliprole exhibited $7,7,12,8,9,11$, and 8 bands, respectively. Untreated control samples showed seven protein bands with molecular weight of $45,31,28,26,17,16$, and $15 \mathrm{kDa}$. Bands with molecular weight of 45,31, 28,26, 17, 16, and $15 \mathrm{kDa}$ were found in both control samples and all samples treated with tested herbicides and insecticide. 
Citation: Reda M. Saba, Ibrahim A. Mohamed, Mohamed A. I. Ahmed, 2018. Toxicological and Biochemical Investigation Of Certain Herbicides on Culex pipiens L. (Diptera: Culicidae) Mosquitos Under Laboratory Conditions. Advances in Natural and Applied Sciences., 12(2): 6-12

Table 1: Lethal toxicity of selected herbicides in comparison with one insecticide on the $4^{\text {th }}$ instar larvae of Culex pipiens after 24-h of exposure.

\begin{tabular}{|c|c|c|c|c|}
\hline Compounds & $\begin{array}{l}\mathrm{LC}_{50}{ }^{\mathrm{a}} \\
(95 \% \mathrm{CL})\end{array}$ & $\begin{array}{l}\mathrm{LC}_{90}{ }^{\mathrm{a}} \\
(95 \% \mathrm{CL})\end{array}$ & $\begin{array}{l}\text { Slope } \\
( \pm \text { SE })\end{array}$ & $n^{\mathrm{b}}$ \\
\hline Thiamethoxam+chlorantraniliprole & $\begin{array}{l}0.0083 \\
(0.0046-0.014)\end{array}$ & $\begin{array}{l}0.032 \\
(0.018-0.14)\end{array}$ & $\begin{array}{l}2.81 \\
( \pm 0.26)\end{array}$ & 280 \\
\hline Mesosulfuron-methyl+iodosulfuron-methyl & $\begin{array}{l}0.67 \\
(0.53-0.86)\end{array}$ & $\begin{array}{l}1.75 \\
(1.21-4.40\end{array}$ & $\begin{array}{l}0.54 \\
( \pm 0.09)\end{array}$ & 280 \\
\hline Clodinafop-propargyl+pinoxaden & $\begin{array}{l}1.34 \\
(0.75-2.58)\end{array}$ & $\begin{array}{l}2.71 \\
(1.75-24.49)\end{array}$ & $\begin{array}{l}0.53 \\
( \pm 0.09)\end{array}$ & 280 \\
\hline Diclofop-methyl & $\begin{array}{l}4.44 \\
(2.14-7.01)\end{array}$ & $\begin{array}{l}16.07 \\
(9.35-104.84)\end{array}$ & $\begin{array}{l}1.49 \\
( \pm 0.15)\end{array}$ & 280 \\
\hline Bromoxynil octanoate & $\begin{array}{l}9.05 \\
(2.28-43.04)\end{array}$ & $\begin{array}{l}36.03 \\
(13.61-103.49)\end{array}$ & $\begin{array}{l}2.04 \\
( \pm 0.18)\end{array}$ & 280 \\
\hline Fenoxaprop-p-ethyl & $\begin{array}{l}28.71 \\
(20.54-40.75)\end{array}$ & $\begin{array}{l}79.45 \\
(52.89-177.70)\end{array}$ & $\begin{array}{l}4.23 \\
( \pm 0.31)\end{array}$ & 280 \\
\hline Glyphosate isopropylamine & $\begin{array}{l}17484.02 \\
(15924.65-19119.80)\end{array}$ & $\begin{array}{l}36110.09 \\
(32025.07-41994.98)\end{array}$ & $\begin{array}{l}17.26 \\
( \pm 1.36) \\
\end{array}$ & 280 \\
\hline
\end{tabular}

${ }^{\mathrm{a}}$ Concentrations are expressed in $\mu \mathrm{g} / \mathrm{ml}$ and the response determined after $24-\mathrm{h}$.

${ }^{\mathrm{b}} n$, no. of larvae tested including control.

Table 2: Lethal toxicity of selected herbicides in comparison with one insecticide on the $4^{\text {th }}$ instar larvae of Culex pipiens after 48-h of exposure.

\begin{tabular}{|c|c|c|c|c|}
\hline Compounds & $\begin{array}{l}\mathrm{LC}_{50}{ }^{\mathrm{a}} \\
(95 \% \mathrm{CL})\end{array}$ & $\begin{array}{l}\mathrm{LC}_{90}{ }^{\mathrm{a}} \\
(95 \% \mathrm{CL})\end{array}$ & $\begin{array}{l}\text { Slope } \\
( \pm \text { SE })\end{array}$ & $n^{\mathrm{b}}$ \\
\hline Thiamethoxam+chlorantraniliprole & $\begin{array}{l}0.0016 \\
(0.00007-0.0028)\end{array}$ & $\begin{array}{l}0.0055 \\
(0.0033-0.040)\end{array}$ & $\begin{array}{l}2.56 \\
( \pm 0.36)\end{array}$ & 280 \\
\hline Mesosulfuron-methyl+iodosulfuron-methyl & $\begin{array}{l}0.45 \\
(0.083-0.73)\end{array}$ & $\begin{array}{l}1.10 \\
(0.69-132.48)\end{array}$ & $\begin{array}{l}1.15 \\
( \pm 0.10)\end{array}$ & 280 \\
\hline Clodinafop-propargyl+pinoxaden & $\begin{array}{l}1.13 \\
(0.62-2.13)\end{array}$ & $\begin{array}{l}2.46 \\
(1.52-20.45)\end{array}$ & $\begin{array}{l}0.20 \\
( \pm 0.08)\end{array}$ & 280 \\
\hline Diclofop-methyl & $\begin{array}{l}2.93 \\
(1.66-4.03)\end{array}$ & $\begin{array}{l}10.28 \\
(7.14-22.18)\end{array}$ & $\begin{array}{l}1.10 \\
( \pm 0.15)\end{array}$ & 280 \\
\hline Bromoxynil octanoate & $\begin{array}{l}4.81 \\
(0.37-23.65)\end{array}$ & $\begin{array}{l}32.21 \\
(10.01-39.63)\end{array}$ & $\begin{array}{l}1.06 \\
( \pm 0.13)\end{array}$ & 280 \\
\hline Fenoxaprop-p-ethyl & $\begin{array}{l}21.63 \\
(6.54-62.48)\end{array}$ & $\begin{array}{l}73.00 \\
(34.72-118.24)\end{array}$ & $\begin{array}{l}3.20 \\
( \pm 0.26)\end{array}$ & 280 \\
\hline Glyphosate isopropylamine & $\begin{array}{l}7042.38 \\
(5762.36-8012.73)\end{array}$ & $\begin{array}{l}13856.87 \\
(12241.68-16717.17)\end{array}$ & $\begin{array}{l}16.76 \\
( \pm 2.69)\end{array}$ & 280 \\
\hline
\end{tabular}

${ }_{\mathrm{a}}^{\mathrm{a}}$ Concentrations are expressed in $\mu \mathrm{g} / \mathrm{ml}$ and the response determined after $48-\mathrm{h}$.

${ }^{\mathrm{b}} n$, no. of larvae tested including control.

Table 3: Lethal toxicity of selected herbicides in comparison with one insecticide on the $4^{\text {th }}$ instar larvae of Culex pipiens after 72-h of exposure.

\begin{tabular}{|c|c|c|c|c|}
\hline Compounds & $\begin{array}{l}\mathrm{LC}_{50}{ }^{\mathrm{a}} \\
(95 \% \mathrm{CL})\end{array}$ & $\begin{array}{l}\mathrm{LC}_{90}{ }^{\mathrm{a}} \\
(95 \% \mathrm{CL})\end{array}$ & Slope ( \pm SE) & $n^{\mathrm{b}}$ \\
\hline Thiamethoxam+chlorantraniliprole & $\begin{array}{l}0.0004 \\
(0.00004-0.00083)\end{array}$ & $\begin{array}{l}0.0023 \\
(0.0013-0.0033)\end{array}$ & $\begin{array}{l}2.12 \\
( \pm 0.35)\end{array}$ & 280 \\
\hline Mesosulfuron-methyl+iodosulfuron-methyl & $\begin{array}{l}0.36 \\
(0.074-0.53)\end{array}$ & $\begin{array}{l}0.89 \\
(0.60-10.17)\end{array}$ & $\begin{array}{l}1.44 \\
( \pm 0.11)\end{array}$ & 280 \\
\hline Clodinafop-propargyl+pinoxaden & $\begin{array}{l}1.05 \\
(0.54-2.01)\end{array}$ & $\begin{array}{l}2.38 \\
(1.44-24.98)\end{array}$ & $\begin{array}{l}0.81 \\
( \pm 0.08)\end{array}$ & 280 \\
\hline Diclofop-methyl & $\begin{array}{l}2.06 \\
(0.67-3.17)\end{array}$ & $\begin{array}{l}8.63 \\
(5.71-23.93)\end{array}$ & $\begin{array}{l}0.65 \\
( \pm 0.15)\end{array}$ & 280 \\
\hline Bromoxynil octanoate & $\begin{array}{l}1.65 \\
(0.043-4.38)\end{array}$ & $\begin{array}{l}19.68 \\
(7.05-25.75)\end{array}$ & $\begin{array}{l}0.26 \\
( \pm 0.12)\end{array}$ & 280 \\
\hline Fenoxaprop-p-ethyl & $\begin{array}{l}16.05 \\
(2.12-41.85)\end{array}$ & $\begin{array}{l}56.99 \\
(28.03-84.66)\end{array}$ & $\begin{array}{l}2.82 \\
( \pm 0.26)\end{array}$ & 280 \\
\hline Glyphosate isopropylamine & $\begin{array}{l}5217.25 \\
(3269.54-6469.88)\end{array}$ & $\begin{array}{l}11157.65 \\
(9707.21-13629.83)\end{array}$ & $\begin{array}{l}14.43 \\
( \pm 3.26)\end{array}$ & 280 \\
\hline
\end{tabular}

${ }^{\mathrm{a}}$ Concentrations are expressed in $\mu \mathrm{g} / \mathrm{ml}$ and the response determined after $72-\mathrm{h}$.

${ }^{\mathrm{b}} n$, no. of larvae tested including control.

New band with molecular weight approximately of $41 \mathrm{kDa}$ was detected in samples treated with glyphosate isopropylamine, bromoxynil octanoate, diclofopmethyl, mesosulfuron-methyl+iodosulfuron-methyl, and thiamethoxam+chlorantraniliprole, while the band of $19 \mathrm{kDa}$ was showed with samples treated by same pesticides except bromoxynil octanoate and thiamethoxam+chlorantraniliprole. Three new bands with molecular weight of approximately 41,22 , and $19 \mathrm{kDa}$ were detected in Culex pipiens larvae samples treated in the same of these herbicides with Glyphosate isopropylamine, diclofop-methyl, and mesosulfuronmethyl+iodosulfuron-methyl. Moreover, new band of $35 \mathrm{kDa}$ was found only on sample treated with diclofop-methyl.

Generally, the herbicides tested in this study have different unique mode of actions. For instance, glyphosate extinguished sensitive weeds by inhibiting the EPSPs enzyme and obstructing the biosynthesis of essential aromatic amino acids and protein whereas iodosulfuron-methyl is considered the inhibitor of the ALS enzyme in the splitted chain amino acid and protein biosynthesis pathway in plants and microorganisms [33]. The target site of bromoxynil is the photosynthetic pathway. Although insects and other animals lack these target sites of these herbicides (i.e., the EPSPs and ALS enzymes or the photosynthetic process) however, the potential defects of glyphosate, bromoxynil and some ALS-inhibitors (i.e., imazethapyr) on survival, development and growth of different non-target invertebrates and vertebrates such as amphibian, fish, horsehair worms (Chordodes nobilii) and various insects have been detected [18, 20, 34-39]. 
Toxicity index from $L_{50}$ values

(A)

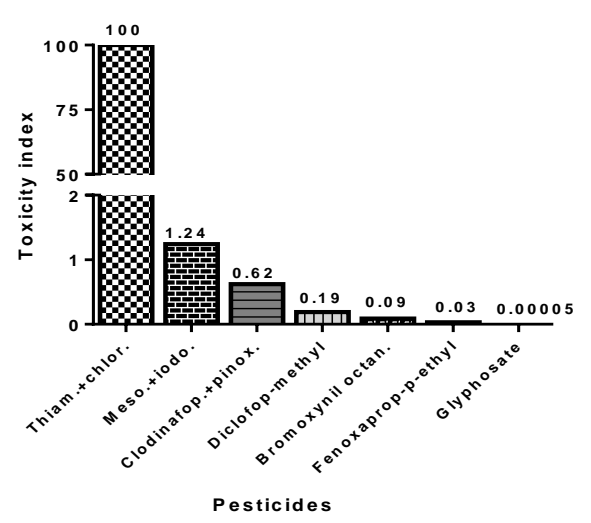

(B)

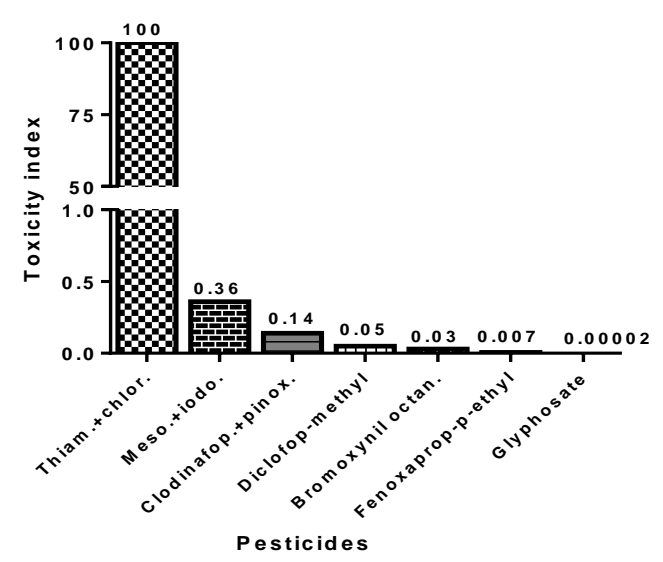

(C)

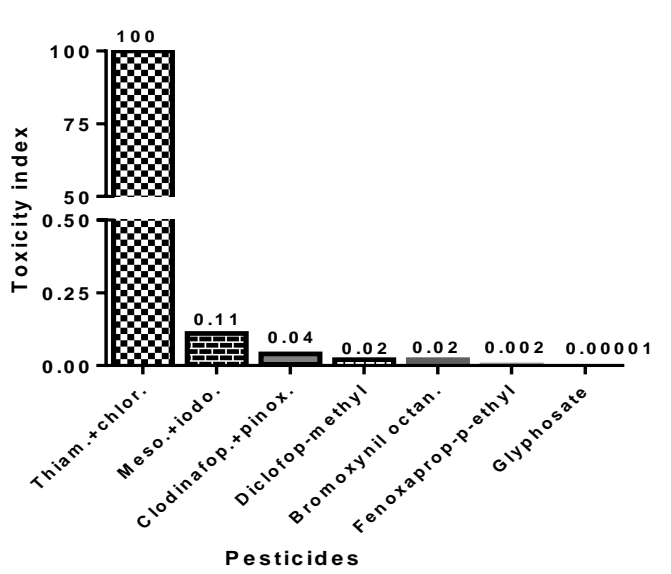

Toxicity index from LC $L_{90}$ values

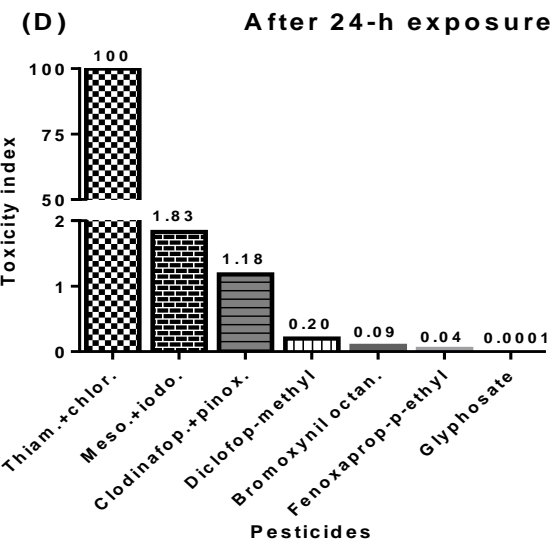

$(\mathrm{E})$

After 48-h exposure

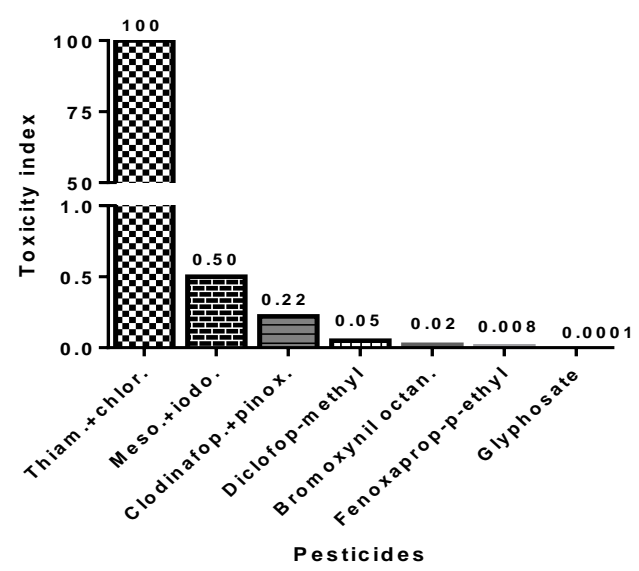

( $F)$

After 72-h exposure

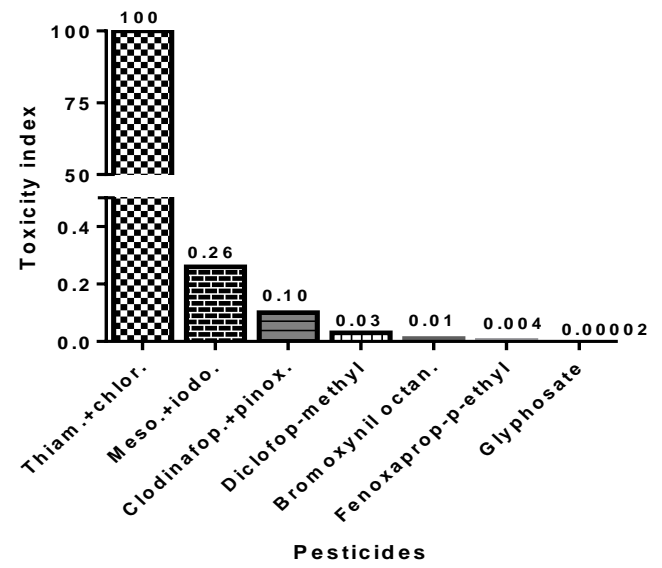

Fig. 1: Toxicity index of certain herbicides in comparison with one insecticide based on $\mathrm{LC}_{50}$ values $(\mathrm{A}, \mathrm{B}$, and $\mathrm{C})$ and based on $\mathrm{LC}_{90}$ values $(\mathrm{D}$, $\mathrm{E}$, and $\mathrm{F})$ on $4^{\text {th }}$ instar larvae of Culex pipiens after 24, 48, and 72-h exposure.

Toxicity index $=[($ LC of the most toxic tested pesticide $/$ LC of the tested pesticide $) \times 100]$. 


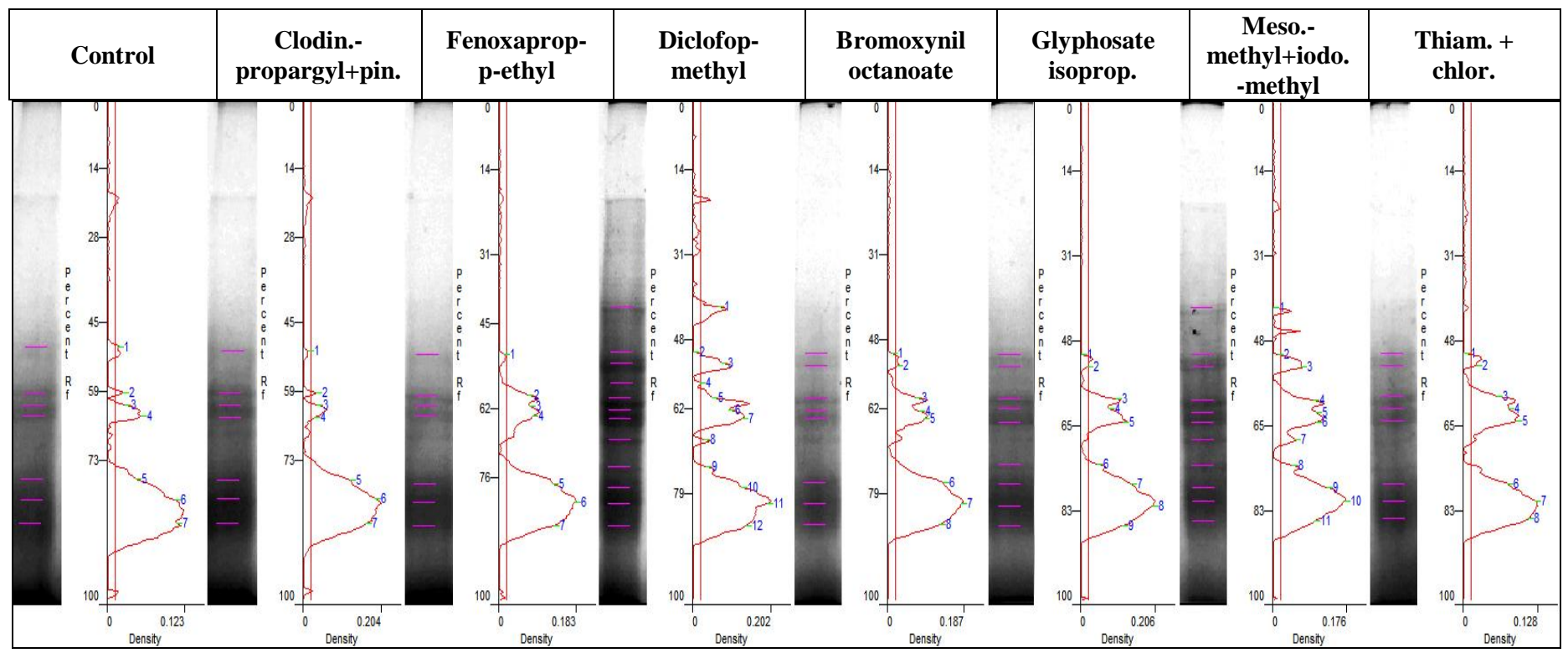

Fig. 2: SDS-protein content electrophoretic profile of selected herbicides in comparison with one insecticide tested against $4^{\text {th }}$ instar larvae of $C$ ulex pipiens.

Table 4: Present (+) and absence (-) protein bands of selected herbicides in comparison with one insecticide tested against $4^{\text {th }}$ instar larvae of Culex pipiens.

\begin{tabular}{|c|c|c|c|c|c|c|c|c|c|}
\hline $\mathrm{MW}^{\mathrm{a}}$ & $\mathrm{R}_{\mathrm{f}}^{\mathrm{b}}$ & Control & $\begin{array}{c}\text { Clodin.- } \\
\text { propargyl+pin. }\end{array}$ & $\begin{array}{l}\text { Fenoxaprop-p- } \\
\text { ethyl }\end{array}$ & $\begin{array}{l}\text { Diclofop- } \\
\text { methyl }\end{array}$ & $\begin{array}{l}\text { Bromoxynil } \\
\text { octanoate }\end{array}$ & $\begin{array}{c}\text { Glyphosate } \\
\text { isoprop. }\end{array}$ & $\begin{array}{c}\text { Meso.- } \\
\text { methyl+iodo.- } \\
\text { methyl }\end{array}$ & Thiam. + chlor. \\
\hline 60 & 41.1 & - & - & - & + & - & - & + & - \\
\hline 45 & 50.2 & + & + & + & + & + & + & + & + \\
\hline 41 & 52.8 & - & - & - & + & + & + & + & + \\
\hline 35 & 56.4 & - & - & - & + & - & - & - & - \\
\hline 31 & 59.0 & + & + & + & + & + & + & + & + \\
\hline 28 & 61.4 & + & + & + & + & + & + & + & + \\
\hline 26 & 63.6 & + & + & + & + & + & + & + & + \\
\hline 22 & 67.7 & - & - & - & + & - & - & + & - \\
\hline 19 & 72.8 & - & - & - & + & - & + & + & - \\
\hline 17 & 76.6 & + & + & + & + & + & + & + & + \\
\hline 16 & 80.3 & + & + & + & + & + & + & + & + \\
\hline 15 & 84.5 & + & + & + & + & + & + & + & + \\
\hline
\end{tabular}

${ }^{\mathrm{a}} \mathrm{MW}=$ Molecular weight is expressed as $\mathrm{kDa}$

${ }^{\mathrm{b}} \mathrm{R}_{\mathrm{f}}=$ Relative migration distance

The mechanism of how these herbicides adversely impact on insects and other animals is unclear. However, several researchers suggested that the herbicides (active ingredients and surfactants) can interfere directly on other target sites on these organisms that due to disrupt effect on their physiological, genetic, and biochemical systems which leading to death or abnormal growth [34-35]. For example, glyphosate and other herbicides had been indicated as an inhibitor to the cytochrome P450 family enzymes (i.e. Cyp450 aromatase) and other numerous enzymes that play a critical role in growth and development of animals through their disruption of the thyroid hormones pathway [34,40]. Herbicide formulations contained its active ingredients and some chemical additives like surfactants and foaming agents and more studies indicated the highly toxic of these surfactants on different aquatic animals and insects than the active ingredients of these herbicides [41]. The $\mathrm{LC}_{50}$ of glyphosate alone and its Roundup formulation on Daphina magna Straus were 962 and 25.5 mg L-1 after 96 h of treatment [42]. Janssens and Stoks (2017) [43] found that the formulation of roundup had greater impacts on insects than their active ingredient alone.

Exposure of larvae of mosquito species to different herbicides (i.e., glyphosate, atrazine) due to induce of different detoxification enzymes such as cytochrome P450 monooxygenases, glutathione S-transferases (GSTs), and esterases that reduce the effectiveness of different insecticides and generate the insecticide-resistant phenomena in mosquitos by increasing the metabolism of these compounds [28].

For example, treatment of Aedes aegypti larvae with glyphosate resulted on increase the induction of P450s, GSTs and carboxylesterase in larvae bodies and conferred the larvae tolerance to the four different insecticides commonly used in mosquitos control, propoxur, B.t., permethrin, and imidacloprid [28, 44].

In the present study, the toxicity effects of glyphosate, bromoxynil, and iodosulfuron on Culex pipiens larvae may occurs through the exposure of larvae to the commercial formulations of these herbicides which contained on the active ingredient of each one plus other chemical materials such as surfactants, dyes and foaming agents that may cause this toxicity effect directly or may play a main role to help the active ingredient to make this action. In agreement with previous studies, the toxicity of glyphosate, iodosulfuron, and bromxynil formulations on Culex pipiens larvae may attribute to the effects of the active ingredients and/or surfactants found in the formulations of these herbicides on physiological and biochemical systems in the insect [18,28].

Fluazifop-p-butyl and fenoxaprop-p-ethyl exhibited high toxicity against Culex pipiens larvae with $\mathrm{LC}_{50}$ values of 2.69 and $2.05 \mu \mathrm{g} / \mathrm{ml}$ after $24-\mathrm{h}$ exposure, respectively [18].

Clodinfop+pinoxaden, diclofop, fenoxaprop are inhibitor of ACCase enzyme and fatty acids biosynthesis in grassy weeds. This ACCase enzyme and this lipid synthesis pathway have also been presented in the insects and other animals such as Toxoplasma gondii [44]. Some ACCase-inhibiting herbicides (i.e., clodinafop) killed some human parasite like $T$. gondii and malaria parasite (Plasmodium falciparum) without any toxicity effect on human cells in the in vitro growth assay [46-48]. In insects, ACCase enzyme play main role in hormones synthesis. Gupta and Bhattacharya (2008) [22] indicated that quizalafop herbicide performed high toxicity on the larvae of Spilartia oblique Walker that may be caused by inhibiting of the ACCase enzyme and blocks the fatty acids synthesis in this insect that may due to the overproduction of ethylene. Also, diclofop showed potential effects against Helicoverpa armigera insect through it interfere on pheromone synthesis [24].

Several studies indicated that exposure of organisms include mosquitoes to herbicides, heavy metals and other xenobiotic as a chemical stress introduced response by synthesizing a new set of proteins. Various herbicides (i.e., glyphosate, atrazine) have been found as xenobiotic materials in the mosquitoes breed sites induced particular metabolic enzymes such as Cyps, esterases, and GSTs [28]. The genotoxicant effects of glyphosate on aquatic snail, Biomphalaria glabrata, 
have been detected by using SDS-PAGE protein profiles assay; and the results demonstrated that the negative effect of glyphosate on the DNA and proteins of the snail were showed on appear and/or absent some bands [19].

Importantly, Culex pipiens larvae that exposed to these herbicides and insecticide may be increase the transcription action of certain genes to induce some enzymes as protein production in the interior of the insect body. However, that could involve in the degradation process of these xenobiotics as initial phase of the defense system.

The surfactant in some commercial herbicide formulations such as Roundup (glyphosate) was more toxic on amphibians than the active ingredient of this herbicide [35].

Gupta and Bhattacharya (2008) [22] indicated that quizalafop and imazethapyr showed high toxicity against larvae of Spilartia oblique Walker and they suggested that this toxicity action might be attributed to the disruption effects of imazethapyr on the amino acids biosynthesis that prevent larvae bodies from its and protein, in the same time the insect cannot make these compounds with them self.

Overall, our study showed the potency of selected herbicides on the $4^{\text {th }}$ instar larvae of Culex pipiens in comparison of one insecticide. Further biochemical and molecular biological investigation such as sequencing the new protein bands that observed with the SDS-protein content experiment to get better understanding about the function of these proteins. Moreover, field and semi-field experiments should be conducted to illustrate the efficacy of these herbicides.

\section{REFERENCES}

[1] Ahmed, M.A.I. and Matsumura F. 2012. Synergistic actions of formamidine insecticides on the activity of pyrethroids and neonicotinoids against Aedes aegypti (Diptera: Culicidae). J. Med. Entomol. 49(6): 1405-1410.

[2] Ahmed, M.A.I., C.F.A. Vogel and F. Matsumura, 2015. Unique biochemical and molecular biological mechanism of synergistic actions of formamidine compounds on selected pyrethroid and neonicotinoid insecticides on the fourth instar larvae of Aedes aegypti (Diptera: Culicidae). Pestic. Biochem. Physiol. 120: 57-63.

[3] Ahmed, M.I.A. and C.F.A. Vogel. 2015. Synergistic action of octopamine receptor agonists on the activity of selected novel insecticides for control of dengue vector Aedes aegypti (Diptera: Culicidae) mosquito. Pestic. Biochem. Physiol. 120:51-56.

[4] Ahmed, M.I.A. and C.F.A. Vogel. 2016. Effects of piperonyl butoxide on the toxicity of novel selected insecticides against Aedes aegypti Adults (Diptera: Culicidae). Australian Journal of Basic and Applied Sciences. 10(12): 248-254.

[5] Abd El-Samie E. and T. Abd El-Baset. 2012. Efficacy of some insecticides on field populations of Culex pipiens (Linnaeus) from Egypt. J Basic Appl Zool, 65, 62-73.

[6] Ahmed, M.I.A. and R.M. Saba, 2016. The Potential efficacy of certain strobilurin and sterol demethylation inhibitor fungicides on Culex pipiens L. (Diptera: Culicidae) Mosquito. Australian Journal of Basic and Applied Sciences. 10(10): 307-311.

[7] Meagan, J.M. Khalil, G.M. Hoogstraal, H. and F.K. Adham, 1980. Experimental transmission and field isolation studies implicating Culex pipiens as a vector of Rift Valley virus in Egypt. Am. J. Trop. Hyg. 80: 1405-1410.

[8] Pelah, D.Z. Abramovich, A. Markus and Z. Wiesman, 2002. The use of commercial saponin from Quillaje saponaria barks as a natural larvicidal agent against Aedes aegypti and Culex pipiens. J. Ethnopharmacol. 81 (3): 407- 409.

[9] Zittra, C., E. Flechl, M. Kothmayer, S. Vitecek, H. Rossiter, T. Zechmeister and H.P. Fuehrer, 2016. Ecological characterization and molecular differentiation of Culex pipiens complex taxa and Culex torrentium in eastern Austria. Parasit. Vectors. 9: 197-205.

[10] Reiter, M.E. and D.A. LaPointe .2007. Landscape factors influencing the spatial distribution and abundance of mosquito vector Culex quinquefasciatus (Diptera: Culicidae) in a mixed residential agricultural community in Hawai'i. J. Med. Entomol. 44(5): 861-868.

[11] Tsui, M.T.K. and L.M. Chu .2008. Environmental fate and non-target impact of glyphosate-based herbicide (Roundup) in a subtropical wetland. Chemosphere. 71(3): 439-446

[12] Morris, A., E.G. Murrell, T. Klein and B.H. Noden, 2016. Effect of two commercial herbicides on life history traits of a human disease vector, Aedes aegypti, in the laboratory setting. Ecotoxicology. 25(5): 863-870.

[13] Zimdahl, R.L., 2007. Fundamental of Weed Science. Academic Press, Inc. Elsevier, San Diego, CA, USA. P. 689.

[14] Mikó Z., J. Ujszegi, Z. Gál and A. Hettyey. 2017. Effects of a glyphosate-based herbicide and predation threat on the behavior of agile frog tadpoles. Ecotoxicol. Environ. Saf. 140: 96-102.

[15] Schulz, R. 2004. Field studies on exposure, effects, and risk mitigation of aquatic nonpoint-source insecticide pollution: a review. J. Environ. Qual. 33: $419-448$.

[16] Russo, J. and L. Lagadic. 2004. Effects of environmental concentrations of atrazine on hemocyte density and phagocytic activity in the pond snail Lymnaea stagnalis (Gastropoda, Pulmonata). Environ. Pollut. 127(2): 303-311.

[17] Kadoum, A.M. and D.E. Mock. 1978. Herbicide and insecticide residues in tailwater pits: water and pit bottom soil from irrigated corn and sorghum fields. J. Agric. Food Chem. 26(1): 45-50.

[18] Mohamed, I.A., M.I.A. Ahmed and R.M. Saba. 2016. Unique efficacy of certain novel herbicides against Culex pipiens (Diptera: Culicidae) mosquito under laboratory conditions. Adv. Environ. Boil. 10(8): 104-111.

[19] Mona, M.H., R.M. Gaafar, I.B. Helal, N.E. Omran and W.M. Salama. 2013. Evaluation of cytotoxic effects of atrazine and glyphosate herbicides on Biomphalaria glabrata snails. J. Basic. Appl. Zool. 66(2): 68-75.

[20] Samsoe, P.L. 1995. Effects of 67 herbicides and plant growth regulators on the rove beetle Aleochara bilineata (Col.: Staphylinidae) in the laboratory. Entomophaga. 40: 95-104.

[21] LaBar C.C. and C.B. Schultz, 2012. Investigating the role of herbicides in controlling invasive grasses in Prairie habitats: Effects on non-target Butterflies. Nat. Areas J. 32(2): 177-189.

[22] Gupta, G. and A.K. Bhattacharya, 2008. Assessing toxicity of post-emergence herbicides to the Spilarctia obliqua Walker (Lepidoptera: Arctiidae). J. Pest. Sci. 81: 9-15.

[23] Abo-El-Ghar, G.E.S. 1994. Effects of herbicides on consumption, growth and food utilization by cotton leaf worm Spodoptera littoralis (Boisd.) larvae. Anz. Schädlingskd. Pfl. Umwelt, 67: 143-146.

[24] Russell, C. and C.B. Schultz. 2009. Effects of grass-specific herbicides on butterflies: an experimental investigation to advance conservation efforts. J. Insect Conserv. 14: 53-63.

[25] Serandour, J., P. Ravanel, M. Tissut, G. Lemperiere and M. Raveton. 2011. Experimental bases for a chemical control of Coquillettidia mosquito populations. Pestic. Biochem. Physiol. 101(2): 65-70.

[26] Bara, J.J., A. Montgomery and E.J. Muturi. 2014. Sublethal effects of atrazine and glyphosate on life history traits of Aedes aegypti and Aedes albopictus (Diptera: Culicidae). Parasitol. Res. 113(8): 2879-2886.

[27] Boyer S, J.P. David, D. Rey, G. Lemperiere and P. Ravanel. 2006. Response of Aedes aegypti (Diptera: Culicidae) larvae to three xenobiotic exposures: Larval tolerance and detoxifying enzyme activities. Environ. Toxicol. Chem. 25: 470-476.

[28] Raiz, M.A., R. Poupardin, S. Reynaud, C. Strode, H. Ranson and J.P. David. 2009. Impact of glyphosate and benzo[a]pyrene on the tolerance of mosquito larvae to chemical insecticides. Role of detoxification genes in response to xenobiotics. Aquat. Toxicol. 93: 61-69.

[29] Zadory, L. and P. Muller. 1981. Potential use of fresh water molluses for monitoring river pollution. Geo. J. 5: 433-445.

[30] World Health Organization (WHO). 1981. Instructions for determining the susceptibility or resistance of mosquito larvae to insecticides. WHO/VBC. 81: 3-6.

[31] Ahmed, M.A.I. and R.M. Saba. 2014. Comparative toxicological evaluation between different formulations of two selected neonicotinoid pesticides on Culex pipiens (Diptera: Culicidae) mosquito. Adv. Environ. Biol. 8(4): 1169-1174. 
[32] Bradford, M.M. 1976. A rapid and sensitive method for the quantitation of microgram quantities of protein utilizing the principle of protein-dye binding Anal. Biochem. 72: 248-254.

[33] Wakabayashi, K. and P. Böger. 2004. Phytotoxic sites of action for molecular design of modern herbicides (part 2): Amino acid, lipid and cell wall biosynthesis, and other targets for future herbicides. Weed Biol. Manag. 4(2): 59-70.

[34] Lanctôt, C., C. Robertson, L. Navarro-Martín, C. Edge, S.D. Melvin, J. and Houlahan, V.L. Trudeau. 2013. Effects of the glyphosate-based herbicide Roundup WeatherMax® on metamorphosis of wood frogs (Lithobates sylvaticus) in natural wetlands. Aquat. Toxicol. 140-141: 48-57.

[35] Lanctôt, C., L. Navarro-Martín, C. Robertson, B. Park, P. Jackman, B.D. Pauli and V.L. Trudeau. 2014. Effects of glyphosate-based herbicides on survival, development, growth and sex ratios of wood frog (Lithobates sylvaticus) tadpoles. II: agriculturally relevant exposures to Roundup WeatherMax ${ }^{\circ}$ and Vision® under laboratory conditions. Aquat. Toxicol. 154:291-303.

[36] Cauble, K. and R.S. Wagner. 2005. Sublethal effects of the herbicide glyphosate on amphibian metamorphosis and development. Bull. Environ. Contam. Toxicol. 75(3): 429-435.

[37] Achiorno, C.L., C. de Villalobos and L. Ferrari. 2008. Toxicity of the herbicide glyphosate to Chordodes nobilii (Gordiida, Nematomorpha). Chemosphere. 71: 1816-1822.

[38] Solomon, K.R. and D.G. Thompson. 2003. Ecological risk assessment for aquatic organisms from over-water uses of glyphosate. J. Toxicol. Environ. Health B Crit. Rev. 6(3): 289-324.

[39] Singh, H. and A.K. Bhattacharya. 2004. Non target effect of post-emergence herbicides on the developmental profile of Spodoptera litura (Fab.). Indian J. Entomol. 66: 42-47.

[40] Krüger, M., P. Schledorn, W. Schrödl, H.W. Hoppe, W. Lutz and A.A. Shehata. 2014 Detection of glyphosate residues in animals and humans. J. Environ. Anal. Toxicol. 4: 210-215.

[41] Tu, M., C. Hurd and J.M. Randall. 2001. Weed control methods handbook: tools and techniques for use in natural areas. The Nature Conservancy, http://tncweeds.ucdavis.edu. P. 219.

[42] Servizi, J.A., R.W. Gordon and D.W. Martens. 1987. Acute toxicity of Garlon 4 and Roundup herbicides to salmon, Daphnia, and trout. Bull. Environ. Contam. Toxicol. 39: 15-22.

[43] Janssens, L. and R. Stoks. 2017. Stronger effects of Roundup than its active ingredient glyphosate in damselfly larvae. Aquat. Toxicol. 193: 210-216.

[44] David, J.P., E. Coissac, C. Melodelima, R. Poupardin, M.A. Riaz, A. Chandor-Proust and S. Reynaud. 2010. Transcriptome response to pollutants and insecticides in the dengue vector Aedes aegypti using next-generation sequencing technology. BMC Genomics. 11: 216-227.

[45] Goldring, J.P. and J.S. Read. 1993. Insect acetyl-CoA carboxylase: enzyme activity during the larval, pupal and adult stages of insect development. Comp. Biochem. Physiol. 106: 855-858.

[46] Goodman, C.D., V. Mollard, T. Louie, G.A. Holloway, K.G. Watson and G.I. McFadden . 2014. Apicoplast acetyl Co-A carboxylase of the human malaria parasite is not targeted by cyclohexanedione herbicides. Int. J. Parasitol. 44(5): 285-289.

[47] Marjanovic, J., D. Chalupska, C. Paten- ode, A. Coster, E. Arnold, A. Ye, G. Anesi, Y. Lu, I. Okun, S. Tkachenko, R. Haselkorn, and P. Gornicki. 2010. Recombinant yeast screen for new inhibitors of human acetyl-CoA carboxylase 2 identifies potential drugs to treat obesity. Proc. Natl. Acad. Sci. USA. 107: 9093-9098.

[48] Ramya, T.N., S. Mishra, K. Karmodiya, N. Surolia and A. Surolia, 2007. Inhibitors of nonhousekeeping functions of the apicoplast defy delayed death in Plasmodium falciparum. Antimicrob. Agents Chemother. 51: 307-316. 